\title{
En mann med endret utseende
}

\author{
En mann i 40-årene med langvarige ryggsmerter kom til konsultasjon \\ sammen med sin kone. Hun syntes at mannen hadde endret utseende \\ i løpet av de siste månedene.
}

En mann i 40-årene, som opprinnelig var fra Afghanistan, kom til konsultasjon hos sin fastlege sammen med sin kone. Han hadde vært sykmeldt fra fysisk arbeid over lengre tid på grunn av korsryggssmerter. MR hadde påvist et prolaps med rotaffeksjon og lavgradig spinalstenose. Kona hadde lagt merke til at han hadde endret utseende $i$ løpet av de siste 5-6 månedene: Han hadde blant annet gått opp i vekt og blitt rund i ansiktet. Ved klinisk undersøkelse hadde mannen et påfallende rundt ansikt, abdominal fedme og tynne ekstremiteter. På grunnlag av kliniske funn ble det startet utredning. Det ble tatt fastende blodprøver, og svarene er gjengitt $i$ tabell 1.

Grunnet påvist lavt s-kortisol ble pasienten raskt innkalt til ny time.

Det kom frem at han hadde brukt en «naturmedisin» som han hadde kjøpt fra hjemlandet og som ble tatt gjennom munnen $i$ pulverform i doser som han anslo til å være på ca. én teskje daglig. Mannen sa at han hadde begynt à bruke pulveret ni måneder før undersøkelsen og at dosen i løpet av de siste fem månedene var blitt økt til én spiseskje daglig. «Naturmedisinen» hadde angivelig hatt god effekt på ryggsmertene. Mannen fortalte at om han lot være å bruke midlet én dag, forverret smerten seg i den grad at han nesten ikke kunne bevege seg.
På grunnlag av kliniske funn og blodprøveresultater mistenkte man tilførsel av glukokortikoider. I samråd med endokrinolog ble «naturmidlet» seponert og substituert med $5 \mathrm{mg}$ prednisolon daglig i gradvis nedtrappende dose.

Kontroll av blodprøver fem dager etter oppstart med prednisolon viste økning av s-kortisol morgenverdi til $39 \mathrm{nmol} / \mathrm{l}(200-650 \mathrm{nmol} / \mathrm{l})$, adrenokortikotropt hormon (ACTH) $<1,1 \mathrm{pmol}$ l $<10,2 \mathrm{pmol} / \mathrm{l})$, aldosteron $185 \mathrm{pmol} / \mathrm{l}$ (7-800 $\mathrm{pmol} / \mathrm{ll}$ og s-anti-21-hydroksylase $<0,03$ antistoffindeks (<0,09 antistoffindeks) samt normalverdier av beinspesifikk alkalisk fosfatase, parathyreoideahormon og senkningsreaksjon. Videre utredning med tanke på endokrinologisk sykdom ble igangsatt. CT abdomen og CT thorax viste normale funn. Serumverdier av testosteron, seksualhormonbindende globulin, follikkelstimulerende hormon, luteiniserende hormon, østradiol, C-peptid og glukosebelastningstest var alle normale.

Da historien om det inntatte pulveret kom frem, oppfattet man pasientens symptomer på Cushings syndrom som forklart, og det ble ikke funnet indikasjon for bildediagnostikk av hypofysen.

Pasienten fortsatte med prednisolon i lav dose $i$ ett år. Han hadde kroniske ryggsmerter, men opplevde ingen forverring. Etter at

\section{Trine Bjørner \\ trine.bjorner@medisin.uio.no Avdeling for allmennmedisin Universitetet i Oslo \\ og Majorstuhuset legegruppe}

Tayyaba Anwar

Medisinsk avdeling Akershus universitetssykehus

Wenche Rødseth Brede

Avdeling for klinisk farmakologi

St. Olavs hospital

Peter Hemmersbach

Farmasøytisk institutt

Universitetet i Oslo

og

Norges laboratorium for dopinganalyse Oslo universitetssykehus

\section{Lars Slørdal}

Avdeling for klinisk farmakologi

St. Olavs hospital

\begin{tabular}{lll}
\hline Tabell 1 Prøvesvar & & \\
\hline Analyse & Prøveresultat & Referanseverdi \\
S-kortisol morgenverdi & $<23 \mathrm{nmol} / \mathrm{l}$ & $200-650 \mathrm{nmol} / \mathrm{l}$ \\
Supprimert adrenokortikotropt hormon & $<1,1 \mathrm{pmol} / \mathrm{l}$ & $<10,2 \mathrm{pmol} / \mathrm{l}$ \\
Alkalisk fosfatase & $118 \mathrm{U} / \mathrm{l}$ & $<105 \mathrm{U} / \mathrm{l}$ \\
$\mathrm{HbA}_{1 \mathrm{c}}$ & $6,2 \%$ & $<6,1 \%$ \\
Triglyserider & $4,45 \mathrm{mmol} / \mathrm{l}$ & $<2,6 \mathrm{mmol} / \mathrm{l}$ \\
Totalkolesterol & $8,2 \mathrm{mmol} / \mathrm{l}$ & $3,3-6,9 \mathrm{mmol} / \mathrm{l}$ \\
LDL-kolesterol & $5,2 \mathrm{mmol} / \mathrm{l}$ & $1,35-4,74 \mathrm{mmol} / \mathrm{l}$ \\
Vitamin $\mathrm{D}_{3}$ & $26 \mathrm{nmol} / \mathrm{l}$ & $50-150 \mathrm{nmol} / \mathrm{l}$ \\
Hemoglobin & $13,2 \mathrm{~g} / 100 \mathrm{ml}$ & $13,4-17,0 \mathrm{~g} / 100 \mathrm{ml}$ \\
\hline
\end{tabular}




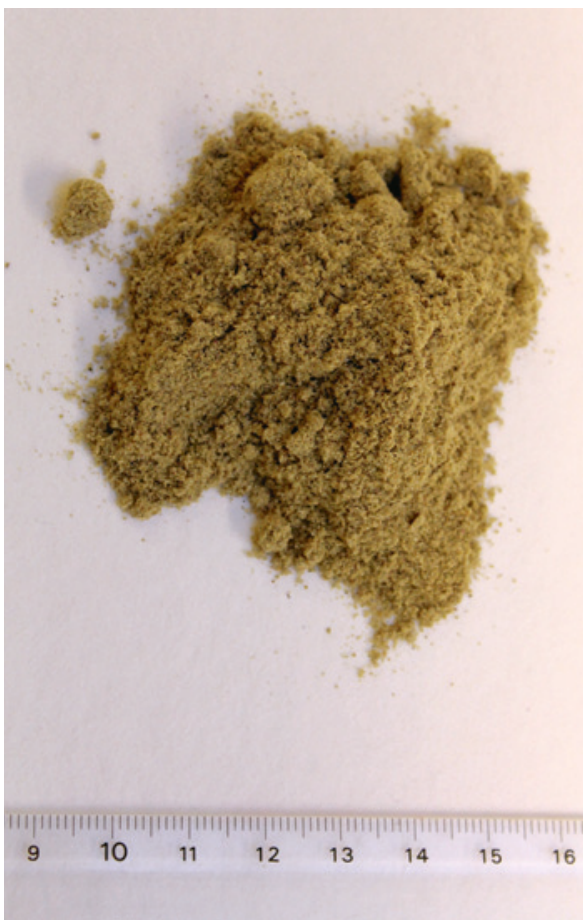

Figur $110 \mathrm{~g}$ av det deksametason-og indometacinholdige «naturmiddel»-pulveret. Foto: Wenche Rødseth Brede

prednisolon ble seponert, ble smertene gradvis verre og han startet med tramadol som smertelindring. Han ble senere operert for lumbalt prolaps. Han har fremdeles smerter i ryggen, men de har avtatt og han håper at han skal komme seg tilbake $i$ arbeid.

Vi har ikke hatt tilgang til emballasjen som pulveret ble solgt $i$, dets produktnavn, innholdsfortegnelse eller produsent. Pasienten samtykket $\mathrm{i}$ at pulveret ble gjenstand for kjemisk analyse. Pulveret var finfordelt og grønnhvitt av farge (fig 1) og avga en aromatisk pepperliknende lukt. Det hadde en spesifikk vekt på ca. $0,33 \mathrm{~g} / \mathrm{ml}$. Pulveret ble løst $\mathrm{i}$ metanol. Det ikke-steroide antiinflammatoriske legemidlet indometacin ble identifisert ved hjelp av gasskromatografi med massespektrometrisk deteksjon (GC-MS) i skanningmodus. Både indometacin og det potente glukokortikosteroidet deksametason ble identifisert mot referansestandarder med væskekromatografi kombinert med massespektrometri (LC-MSMS) med bruk av et trippelkvadrupol - og et kvadrupol-time-of-flight instrument med elektrosprayinjeksjon.

Indometacin- og deksametasoninnholdet $\mathrm{i}$ pulveret ble kvantifisert ved hjelp av væskekromatografi og massespektrometri (LCMS). Kort fortalt ble metanolløsninger av pulveret i til sammen fem forskjellige konsentrasjoner (2-500 $\mathrm{mg}$ pulver $/ \mathrm{ml}$ metanol) injisert på LC-MS-instrumentet og mengdebestemt mot standardkurver av renstoff av indometacin og deksametason. Pulveret inneholdt $0,1 \mathrm{mg}$ deksametason per gram og 9,2 mg indometacin per gram.

Én toppet teskje og én spiseskje av pulveret inneholdt henholdsvis ca. $1 \mathrm{~g} \mathrm{og} 4 \mathrm{~g}$, noe som betyr at liknende mengder inntatt pulver tilførte brukeren henholdsvis $0,1 \mathrm{mg}$ og $0,4 \mathrm{mg}$ deksametason og ca. $10 \mathrm{mg}$ og $40 \mathrm{mg}$ indometacin. Til sammenlikning er de definerte døgndosene for deksametason og indometacin på henholdsvis $1,5 \mathrm{mg} \mathrm{og} 100 \mathrm{mg}$ (1).

\section{Diskusjon}

Noen såkalte naturmedisiner (herbal medicinal products) kan være beheftet med bivirkninger (2). I følge Bransjerådet for naturmidler bruker vi i Norge naturmidler og kosttilskudd for mer enn 2 milliarder kroner $\mathrm{i}$ året (3). Trass $\mathrm{i}$ at behandling med naturmidler er utbredt (4), kan informasjon om pasientenes inntak av slike midler være mangelfull (5). Naturmidlene kan - avhengig av innhold - betraktes som enten kosttilskudd eller legemidler, og import av begge disse produktkategoriene er omfattet av restriksjoner (6). Naturmedisiner brukes $\mathrm{i}$ økende grad i hele den vestlige verden (2). Det store omfanget aktualiserer sikkerhetsaspektene knyttet til bruken. Potensielle sikkerhetsrisikoer omfatter:

- direkte toksisitet. Dette er blant annet rapportert etter bruk av kava (Piper methysticum), som hevdes å ha beroligende effekt, og aristolochia, som hevdes å ha betennelsesdempende effekter. Begge er utbredt i tradisjonell kinesisk medisin (7).

- interaksjoner. Johannesurt er et veldokumentert eksempel (8).

- kontaminering, ofte med tungmetaller.

- tilsetning av andre og uventede virkestoffer som kan inkludere regulære farmaka (2). Dette kalles på engelsk «adulteration», som i vår sammenheng kan oversettes med forfalskning.

I den tidligste rapporten vi har funnet om denne type forfalskninger i faglitteraturen rapporteres agranulocytose etter eksposisjon for et kinesisk naturmiddel som ved analyse viste seg å inneholde de analgetiske midlene aminopyrin og fenylbutason (9). Engelske forskere skrev i 1979 om en kvinne med revmatoid artritt som i 1977 begynte å bruke «Chuei-Fong-Tou-Geu-Wan» (som av forfatterne ble oversatt fra kinesisk til et uttrykk av typen «å jage vinden gjennom beinpipene» - en betegnelse som må sies å overgå de fleste markedsføringspåfunnene fra legemiddelindustrien!) med initialt frapperende effekt. Midlet var angitt å inneholde ekstrakter fra 23 forskjellige planter. På samme måte som i vårt tilfelle viste det seg å inneholde deksametason og indometacin (10). Flere liknende kasuistikker og serier, som blant annet er oppsummert i en systematisk oversiktsartikkel (11), har senere kommet til. I en relativt ny oversiktsartikkel med oppsummering av 26 samleanalyser om temaet fokuseres det på slike «naturmidlers» tilsetninger av støv, pollen, hele eller deler av insekter, vev fra smågnagere, parasitter, mikrober, sopp, mugg, toksiner, plantevernmidler, tungmetaller og mer eller mindre regulære legemidler. Følgene av inntak kan være alvorlig sykdom eller død. Oversiktsartikkelen understreker blant annet at vi mangler informasjon om omfanget av kontaminasjon eller forfalskning og peker på at fenomenet er relativt vanlig $\mathrm{i}$ «naturmidler» produsert $\mathrm{i}$ for eksempel India eller Kina (12).

\section{Konklusjon}

Denne historien illustrerer at naturmidler ikke alltid er verken naturlige eller harmløse. Vår pasient inntok et middel som slett ikke bare inneholdt «naturlige» ingredienser. Opplysningene om dosering er usikre, og det uttalte symptombildet på Cushings syndrom som denne pasienten fremviste, kan tyde på at doseringen har vært høyere enn angitt.

I det beskrevne tilfellet kunne forløpet blitt dramatisk. Pasienten kunne i verste fall utsatt seg for en Addison-krise hvis han på egen hånd hadde bråseponert "naturmedisinen». Historien understreker viktigheten av at man ved anamneseopptak aktivt innhenter opplysninger om alternativ behandling. Historien understreker også behovet for at denne type produkter på samme måte som legemidler blir gjenstand for stringent kvalitetskontroll.

Pasienten har gitt samtykke til at artikkelen blir publisert.

\section{Trine Bjørner (f. 1953)}

er dr.med., spesialist i allmennmedisin, førsteamanuensis og fastlege.

Forfatter har fylt ut ICMJE-skjemaet og oppgir ingen interessekonflikter.

\section{Tayyaba Anwar (f. 1970)}

er lege i spesialisering i indremedisin.

Forfatter har fylt ut ICMJE-skjemaet og oppgir ingen interessekonflikter.

\section{Wenche Rødseth Brede (f. 1951)}

er m.sc. og spesialbioingeniør.

Forfatter har fylt ut ICMJE-skjemaet og oppgir ingen interessekonflikter. 


\section{Peter Hemmersbach (f. 1950)}

er dr.rer.nat, diplomkjemiker, professor II og laboratorieleder.

Forfatter har fylt ut ICMJE-skjemaet og oppgir ingen interessekonflikter.

\section{Lars Slørdal (f. 1955)}

er dr.med., spesialist i klinisk farmakologi, professor og overlege.

Forfatter har fylt ut ICMJE-skjemaet og oppgir ingen interessekonflikter.

\section{Litteratur}

1. Legemiddelforbruket i Norge.

www.legemiddelforbruk.no (1.3.2014).

2. Ernst E. Risks of herbal medicinal products. Pharmacoepidemiol Drug Saf 2004; 13: 767-71.

3. Gaarder J. Her er ekspertenes dom over helsekosten. www.dagbladet.no/2014/04/03/tema/ pluss/helse/kosttilskudd/naturmidler/32619876/ (3.4.2014)

4. Harris PE, Cooper KL, Relton C et al. Prevalence of complementary and alternative medicine (CAM) use by the general population: a systematic review and update. Int J Clin Pract 2012: 66: 924-39.

5. Djuv A, Nilsen OG, Steinsbekk A. The co-use of conventional drugs and herbs among patients in Norwegian general practice: a cross-sectional study. BMC Complement Altern Med 2013; 13: 295-305.

6. Toll. Kosttilskudd. www.toll.no/no/bedrift/ varer-inn-til-norge/restriksjoner-og-forbud/ varer-med-restriksjoner/kosttilskudd/ (3.4.2014).

7. Øvrehus MA, Spigset O, Zahlsen K et al. En ung kvinne med nyresvikt. Tidsskr Nor Legeforen 2011 131: 1897-9.

8. Henderson L, Yue QY, Bergquist C et al. St John's wort (Hypericum perforatum): drug interactions and clinical outcomes. Br J Clin Pharmacol 2002. 54: $349-56$

9. Ries CA, Sahud MA. Agranulocytosis caused by Chinese herbal medicines. Dangers of medications containing aminopyrine and phenylbutazone. JAMA 1975: 231: 352-5

10. Forster PJG, Calverley M, Hubball S et al. ChueiFong-Tou-Geu-Wan in rheumatoid arthritis. BMJ 1979; 2: 308 .

11. Ernst $E$ Cardiovascular adverse effects of herbal medicines: a systematic review of the recent literature. Can J Cardiol 2003; 19: 818-27.

12. Posadzki P, Watson L, Ernst E. Contamination and adulteration of herbal medicinal products (HMPs) an overview of systematic reviews. Eur J Clin Pharmacol 2013; 69: 295-307.

Mottatt 31.7. 2014, første revisjon innsendt 27.11. 2014, godkjent 16.12. 2014. Redaktør: Hanne Støre Valeur. 